\title{
PELAYANAN KEMENTERIAN AGAMA TERHADAP PENGANUT AGAMA BUDDHA DI KOTA PAREPARE SULAWESI SELATAN
}

\author{
Religious Ministry Service for Buddhist in Parepare South Sulawesi
}

\author{
Abd. Shadiq Kawu \\ Balai Litbang Agama Makassar \\ Alamat: Jl. AP Pettarani no 72 Makassar \\ Email : askawu@gmail.com
}

Naskah diterima tanggal 4 Mei 2013. Naskah direvisi tanggal 18 Juli 2013. Naskah disetujui tanggal 31 Juli 2013

\begin{abstract}
Abstrak
Penelitian ini adalah penelitian yang menelusuri pelayanan Kementerian Agama kepada penganut agama Buddha di Kota Perepare, Sulawesi Selatan. Penelitian ini berfokus pada tiga masalah penelitian, yaitu; bagaimana pelayanan kementerian agama terhadap penganut agama Buddha, faktor-faktor yang mempengeruhi kualitas pelayanan, dan tanggapan tokoh agama dan tokoh masyarakat terhadap pelayanan yang diberikan kepada penganut Buddha. Penelitian ini menggunakan metode kualitatif dengan teknik pengumpulan data melalui wawancara, observasi, dan studi dokumen. Analisis data dengan metode deskriptif-analitis. Pelayanan yang diberikan kepada umat Buddha di Kota Parepare dalam bidang penyiaran agama, yaitu dengan menyediakan tiga tenaga penyuluh agama, satu diantaranya adalah penyuluh agama yang berstatus PNS. Pelayanan dibidang penidikan agama adalah bantuan dari kanwil kemenag Sulsel berupa bantuan kepada dua Sekolah Minggu Buddhis yang ada di Kota Parepare. Pelayanan dalam hal tempat ibadah, adalah pemberian rekomendasi dan izin pendirian vihara. Faktor yang mempengaruhi kualitas pelayanan adalah problem minimnya jumlah SDM selaku stake holder pemberi layanan, tidak adanya alokasi anggaran untuk pelayanan keagamaan kepada penganut agama Buddha oleh kementerian agama Parepare, tidak adanya struktur penyelenggara bimas agama Buddha di lingkungan kemenag kota Parepare, dan tidak adanya sarana dan pra sarana yang menunjang maksimalisasi penyelenggaraan pelayanan yang diberikan kepada penganut agama Buddha. Tokoh agama dan tokoh masyarakat menyoroti mnimnya pemberian pelayanan terhadap penganut agama Buddha di Parepare.
\end{abstract}

Kata kunci: Kementerian Agama, pelayanan agama, Budha, Parepare

\begin{abstract}
Research was to track down the religious ministry service for Buddhist in PArepare, South Sulawesi. Research focused in three issues: How did ministry of religious serve the buddhist? What factors affecting to the quality service? What was the comment of community figures to the service? Research was qualitative. Data gained through interview, observation, and document study and analyzed descriptively and analytically. Research found that religious service in religious proselytizing was implemented by supplying three Budha proselytizers, one of them was a local civil servant. In education, religious ministry has done a good turn to two Weekend School. In place of worship service, institution issued recommendation and permit to build vihara. Factors that affecting to the institution quality service is the number of person running the service which was insufficient, no definite financial allocation, no management structure, and no facility to maximize the service. Religious and community figures were very critical to the service.
\end{abstract}

Keywords: religious ministry, Budha, Parepare 


\section{PENDAHULUAN}

A gama Buddha di Indonesia meski terbilang minoritas, termasuk dalam agama yang diberikan pelayanan oleh kementerian agama. Sejak tahun 2006 melalui Perpres No. 63 tahun 2005 tertanggal 14 Oktober 2005 yang kemudian ditindaklanjuti dengan PMA No. 3 tahun 2006 tertanggal 24 Januari 2006, resmilah berdiri Direktorat Jendral Bimbingan Masyarakat Buddha, yang sebelumnya sejak tahun 1966 tergabung dengan agama Hindu dalam Dirjen Bimas Hindu dan Buddha (www.bimasbuddhakemenag.go.id, $1 / 5 / 2013)$.

kementerian telah bertekad untuk meningkatkan kualitas pelayanan bagi setiap pemeluk agama. Hal ini tertuang dalam RPJMN 2010-2014 pada poin ketiga, yaitu "Peningkatan pelayanan bagi umat beragama untuk mendukung upaya peningkatan kualitas pemahaman dan pengamalan agama bagi masyarakat". Pelayanan keagamaan pada hakikatnya merupakan program pemerintah untuk meningkatkan kualitas keberagamaan masyarakat (Rencana Strategis Badan Litbang dan Diklat Kementerian Agama 2010-2014, 2010: 38-39).

Meski dalam struktur pelayanan telah memiliki Dirjen sendiri, bukan berarti pelaksanaan pelayanan terhadap umat Buddha dapat dijalankan dengan maksimal. Stakeholder pelaksana pelaksanaan terhadap umat buddha pada struktur di bawahnya maupun tenaga teknis pelayanan seperti guru dan penyuluh agama buddha, masih sangat kurang. Tidak maksimalnya pelayanan ini membuat kementerian agama kerap mendapatkan keluhan dan sorotan karena pelayanan yang diberikan masih jauh dari yang diharapkan. Belum lagi, karena berposisi sebagai minoritas, umat Buddha kerap mendapatkan perlakuan diskriminatif, khususnya dalam pendirian rumah ibadah.

Parepare merupakan salah satu kota di provinsi Sulawesi Selatan dengan populasi umat Buddha yang cukup signifikan. Telah lama kota Parepare didatangi oleh pendatang yang menganut agama Buddha, baik dari etnik Tionghoa maupun dari etnik Jawa. Penganut Buddha di kota Parepare telah menyatu dalam sebuah hubungan sosial dengan masyarakat lainnya di Parepare. Populasi umat Buddha di Parepare lebih dari $1 \%$ jumlah penduduk kota Parepare, dan di kota tersebut terdapat empat wihara dan empat yayasan agama Buddha. Melihat populasi umat Buddha di kota Parepare, meski minoritas namun mereka tetap punya hak atas pelayanan keagamaan dari kementerian agama sebagaimana yang diterima oleh penganut agama lainnya.

Berdasarkan hal di atas, Balai Litbang Agama Makassar menelusuri lebih jauh terkait pelayanan kepada penganut agama Buddha yang diberikan oleh kementerian agama, dan penelitian ini mengambil lokasi di kota Parepare provinsi Sulawesi Selatan.

Permasalahan dalam penelitian ini adalah bagaimana kualitas pelayanan kementerian agama terhadap penganut agama Buddha di kota Parepare?, apa faktor yang mempengaruhi kualitas pelayanan kementerian agama terhadap penganut agama Buddha di Parepare? dan bagaimana tanggapan masyarakat terhadap pelayanan kementerian agama terhadap penganut agama Buddha di Parepare?.

Penelitian ini memahami pelayanan keagamaan sebagai penjabaran dari RPJMN 20102014 poin ketiga, yaitu: "Peningkatan pelayanan bagi umat beragama untuk mendukung upaya peningkatan kualitas pemahaman dan pengamalan agama bagi masyarakat. Pelayanan keagamaan pada hakikatnya merupakan program pemerintah untuk meningkatkan kualitas keberagamaan masyarakat".

Selain itu penelitian ini juga memahami pelayanan keagamaan sebagai perwujudan dari visi dan misi Dirjen Bimas Buddha Kementerian Agama, yaitu visi terwujudnya masyarakat Buddha Indonesia yang taat beragama, maju, sejahtera, dan harmonis dalam wadah NKRI (Supartini dkk, 2009: 2). Aspek pelayanan yang dimaksud secara spesifik dalam penelitian ini adalah pelayanan kementerian agama terhadap penganut agama Buddha, di bidang penyiaran agama, pendidikan agama: , dan tempat ibadah.

Penelitian pelayanan Kemenag terhadap penganut Buddha telah dilakukan di lingkungan Kemenag. Misalnya penelitian yang dilakukan oleh Mursyid Ali (2008: 195-207), peneliti Balai Litbang Agama Jakarta, meneliti "pelayanan Keagamaan bagi Umat Buddha di Palembang". Penelitian tersebut menemukan bahwa terhambatnya pelayanan keagamaan terhadap penganut agama Buddha di Palembang disebabkan oleh minimnya anggaran, keterbatasan sumber daya manusia, prasarana, dan sarana, terutama transportasi karena pemeluk Buddha berdomisili diberbagai tempat yang berjauhan.

Mengenai penelitian pelayanan keagamaan, khususnya terhadap penganut agama minoritas, 
tahun 2011 Balai Litbang Agama Makassar telah mengadakan penelitian terkait pelayanan Kementerian Agama terhadap Penganut Agama Khonghucu di Kawasan Timur Indonesia (Kawu, 2011). Penelitian tersebut menemukan problem pelayanan terhadap penganut agama Khonghucu disebabkan adanya problem eksistensial yang tidak terdata dengan jelas dalam statistik, termasuk di Kemenag serta belum adanya stake holder yang diberikan tugas untuk memberikan pelayanan keagamaan terhadap penganut agama Khonghucu, baik di bidang pendidikan agama, penyiaran agama, maupun pelayanan keagamaan lainnya. Sehingga dapat dikatakan umat Khonghucu belum tersentuh sama sekali oleh pelayanan dari Kemenag.

\section{Kajian Teori}

\section{Pelayanan Publik}

Pelayanan publik atau pelayanan umum dapat diartikan sebagai segala bentuk jasa pelayanan, baik berbentuk barang maupun jasa publik. Pelayanan publik ini pada dasarnya merupakan tanggung jawab yang dilaksanakan oleh instansi pemerintah, baik di pusat maupun di daerah, sebagai upaya memenuhi kebutuhan masyarakat berdasarkan ketentuan peraturan perundangundangan. Di Indonesia pelayanan publik sering juga diartikan sebagai publik service (Ratminto dan Atik SP, 2007: 4).

Menurut Kepmenpan No. 63/KEP/M. PAN/7/2003, pelayanan publik adalah segala kegiatan pelayanan yang dilaksanakan oleh penyelenggara pelayanan publik sebagai upaya pemenuhan kebutuhan penerimaan pelayanan maupun pelaksanaan ketentuan peraturan perundang-undangan. Dengan demikian, pelayanan publik adalah pemenuhan kebutuhan masyarakat oleh penyelenggara negara. Hal ini terkait dengan fungsi pemerintah dalam pelayanan publik yaitu enviromental service (pelayanan lingkungan), depelovment service (pelayanan pengembangan), dan protective service (perlindungan) (Sutopo dan Adi Suryanto, 2009: 9).

\section{Pelayanan Kementerian Agama Terhadap Penganut Agama Buddha}

Kementerian agama adalah institusi negara yang diamanatkan untuk memberikan pelayanan keagamaan kepada semua pemeluk agama secara adil dan proporsional. Dirjen Bimas Buddha dan struktur di bawahnya adalah stake holder Kemenag yang ditugasi langsung untuk memberikan : kepada penganut Buddha.

Dalam melaksanakan program pelayanannya, Dirjen Bimas Buddha mendasarkan pada visi dan misi. Visinya terwujudkan masyarakat Budda Indonesia yang taat beragama, maju, sejahtera, dan harmonis dalam wadah NKRI. Adapun misi, pertama meningkatkan kualitas bimbingan, pemahaman, pengalaman, dan pelayanan kehidupan beragama Buddha. Kedua meningatkan penghayatan moral dan etika keagamaan Buddha. Ketiga meningkatkan kualitas pendidikan di lingkungan umat Buddha. Keempat memberdayakan umat beragama Buddha dan lembaga keagamaan Buddha untuk kemajuan bangsa dan negara. Kelima menciptakan suasana harmonis dalam memperkokoh kehidupan umat beragama. Keenam mengembangkan keselarasan pemahaman keagamaan : dan wawasan kebangsaan Indonesia (Supartini dkk, 2009: 2). Adapun pelayanan keagamaan yang diberikan kepada umat Buddha menurut Supartini dkk (2007: 4243) mencakup tiga hal: pembinaan bimbingan dan penerangan agama Buddha; pembinaan sarana keagamaan Buddha; serta pembinaan pendidikan agama dan pendidikan keagamaan Buddha.

\section{Keberhasilan Pelayanan Keagamaan}

Untuk melihat keberhasilan pelayanan keagamaan yang diberikan menurut Badrun (2008: 6) ada lima indikator yakni: realibility yakni pemberian pelayanan tepat sasaran; tangibles kualitas sumber daya manusia dan sumber daya lainnya yang memadai; responsivnes pelayanan secara tepat; asurance perhatian terhadap etika dan moral dalam memberikan pelayanan; serta emphaty kemauan untuk memahami dan mengerti keinginan dan kebutuhan konsumen.

Tak kalah pentingnya adalah in put, proses, dan out put dalam pelayanan tersebut. In put merupakan prasyarat terjadinya proses pelayanan, sedangkan out put adalah apa hasil yang telah dicapai dari proses tersebut. Dalam hal ini, in put berupa sumber daya, perangkat lunak, dan harapan-harapan. Sementara proses dimaksudkan sebagai "berubahnya sesuatu menjadi yang lain". Terkait pelayanan keagamaan, proses itu antara lain berupa pengambilan keputusan dan pengelolaan kelembagaan instansi Kemenag. Sedangkan out put merupakan kinerja yang dihasilkan berupa pelayanan terhadap aktivitas keagamaan. Out put menunjukkan hasil nyata pelayanan sesuai sasaran yang diharapkan (Badrun, 2008: 6-7). 


\section{METODE PENELITIAN}

Penelitian ini merupakan penelitian kualitatif dengan memberikan analisis deskriptif. Pengumpulan data dilakukan melalui wawancara mendalam, observasi, dan dokumentasi. Adapun data-data yang digali adalah sejarah awal singkat tentang masyarakat Buddha di Parepare, program Kemenag, teknis pelaksanaan pelayanan Kemenag, problem-problem yang dihadapi dalam melakukan pembinaan, tanggapan tokoh-tikoh aga,a terhadap pelayanan Kemenag.

Pemilihan informan dilakukan secara purposive, yakni memilih informan yang berkaitan erat dengan tema penelitian. Informan yang dipilih adalah mereka yang mudah diajak bicara, mengerti tentang informasi yang peneliti butuhkan, dan yang senang diajak bekerjasama (Endraswara, 2006: 121). Wawancara dilakukan pada instansi terkait seperti Kemenag, pengurus wihara, dan yayasan Buddhis, juga kepada tokoh masyarakat Buddha yang ada di kota Parepare.

Observasi diperlukan untuk mengamati kehidupan keagamaan masyarakat Buddha, kondisi atau tempat pelayanan keagamaan, petugas dalam melayani masyarakat, serta proses pelayanannya. Sedangkan data sekunder diperoleh melalui data kependudukan dan data umat Buddha di kota Parepare, foto-foto, dokumen dan lain-lain. Analisis data penelitian ini tidak hanya dijelaskan dengan menggunakan kalimat-kalimat yang dideskripsikan, tetapi sedapat mungkin memberikan kejelasan objek penelitian (Maleong, 2000: 36).

\section{PEMBAHASAN}

\section{Kondisi Demografis dan Budaya}

Berdasarkan data BPS Kota Parepare 2011, penduduk Kota Parepare berjumlah 117.063 jiwa yang tersebar di empat Kecamatan dan 22 Kelurahan dengan jumlah penduduk terbanyak yaitu Kecamatan Soreang dengan 37.574 jiwa. Masyarakat Parepare majemuk dari berbagai etnik dengan dominasi suku Bugis, Mandar, Makassar, serta Toraja selebihnya etnis Cina dan Jawa.

Makka menggelari kota Parepare sebagai kota orang-orang aneh (2006: 36-38). Istilah itu muncul salah satunya terkait dengan keberadaan orang-orang Cina di daerah ini. Menurut Makka, orang-orang Cina juga senang duduk "kongkowkongkow", khususnya di jalan Baso Daeng Patompo. Saat itu, demikian Makka, mereka juga dianggap orang aneh karena setiap mereka duduk bersama mereka bercakap-cakap sambil teriak-teriak seperti orang bertengkar. Belakangan baru diketahui, oleh Makka bahwa orang China jika bertemu antara satu dengan lainnya, mereka bercakap-cakap dengan suara keras, karena di samping tradisi juga, agar bisa saling memahami apa yang diucapkan. Tradisi suara keras itu terjadi karena nenek moyang mereka dulu tinggal di rumah yang berjauhan antara satu dengan lainnya sehingga jika mereka memanggil tetangganya, harus dengan suara keras. Di samping itu orang China yang ada di : ternyata berasal dari berbagai suku.

\section{Kehidupan Keagamaan}

Kota Parepare memiliki lingkungan sosial yang relatif kondusif dan dikenal sebagai salah satu kota heterogenitas dan pluralitas masyarakatnya yang cukup tinggi. Adapun komposisi penduduk berdasarkan jumlah agama di Kota Parepare berdasarkan data Kemenag kota Parepare yaitu umat Islam berjumlah 121.000 jiwa atau 87,66 \%, Kristen sebanyak 8.104 penganut atau 5,87\%, penganut Katolik sebanyak 5.243 jiwa atau 3,60 \%, umat Hindu (sebagian besar adalah umat Hindu Tolotang) berjumlah 1.826 jiwa atau 1,27 \%, umat Buddha juga jumlahnya sama dengan umat Hindu, yatu berjumlah $1,27 \%$ atau 1.826 penganut, dan penganut Khonghucu berjumlah 534 jiwa atau 0,33 $\%$. Sedangkan untuk rumah ibadah bagi umat Islam terdapat 122 masjid dan 27 mushalah, untuk umat Kristen terdapat 14 gereja, umat Katolik memiliki 1 gereja dan 1 kapel, umat Hindu memiliki 1 sanggah, dan umat Buddha memiliki empat vihara, sedangkan penganut Khonghucu belum memiliki tempat ibadah (Sumber Kementerian Agama Parepare, 2012).

Untuk pembinaan keagamaan di kota Parepare, untuk umat Islam terdapat 18 orang ulama, 100 orang mubalig, 122 khatib, dan 487 guru mengaji. Selain itu untuk pembinaan kehidupan keagamaan umat Islam terdapat 151 majelis taklim dan 97 taman pendidikan Al Quran. Untuk umat Kristen terdapat 22 orang pendeta, 130 orang penatua, 77 orang daken, 7 orang guru injil, 6 orang vikaris, serta 136 orang guru sekolah minggu. Pembinaan keagamaan untuk umat Katolik oleh 1 orang pastur, 5 orang suster, dan 1 orang katekis. Untuk umat Hindu dibina oleh 1 orang pandita, untuk umat Buddha terdapat 1 orang bhikhu dan 6 orang pandita, sedangkan untuk umat Khonghucu tidak terdapat rohaniawan. Untuk tenaga penyuluh 
bagi umat Islam terdapat 16 penyuluh fungsional PNS dan 102 penyuluh honorer, untuk umat Kristen terdapat 1 penyuluh PNS dan 12 penyuluh honorer, umat Katolik belum memiliki penyuluh PNS, tapi terdapat 6 tenaga penyuluh honorer yang bertugas, untuk umat Buddha dilayani oleh 1 orang penyuluh PNS dan 2 orang penyuluh honorer, sedangkan bagi umat Hindu dan Khonghucu belum disediakan tenaga penyuluh baik yang PNS maupun honorer (Sumber Kementerian Agama Parepare, 2012).

\section{Umat Buddha di Parepare: Sejarah Singkat dan Dinamika Sosial \\ Sejarah kehadiran umat Buddha di Sulsel dan Parepare}

Tidak ada catatan jelas tentang sejarah awal kedatangan penganut Buddha di Parepare. Namun, beberapa temuan arkeologis menunjukkan, bahwa setidaknya di masa lalu, umat Buddha pernah menoreh jejak di wilayah ini. Penemuan arca Buddha di Selayar menunjukkan bahwa ada hubungan antara penduduk Sulsel dengan umat Buddha. Menurut Yonggris Lao (wakil ketua Walubi Sulsel) sejarah kedatangan umat Buddha di Sulsel ini setidaknya dibagi ke dalam dua periode, yaitu zaman Sriwijaya dan zaman kolonial hingga kemerdekaan. Meski tidak cukup banyak bukti tentang hubungan antara Sriwijaya dan kerajaan-kerajaan di Sulsel, namun ada asumsi yang menyatakan bahwa salah satu kelompok yang memperkuat armada laut Sriwijaya adalah pelaut-pelaut dari suku Bugis. Selanjutnya kedatangan umat Buddha di Sulsel berdasarkan temuan arkeologis, menurut Edward Polinggomang bahwa orang-orang Tionghoa (yang sebagian diantaranya menganut Buddha) sudah ada di Makassar sekitar abad 13-14 dan resmi masuk pada tahun 1618. Menurut analisis Joyce Ghani kedatangan orang-orang Tionghoa di Makassar sekitar zaman dinasti Yuang (1280-1367) (Rais, 2011: 65).

Untuk Parepare, keberadaan pelabuhan Bacukiki yang tersohor sebagai salah satu bandar niaga terbesar di Sulwesi Selatan, khususnya sekitar abad ke-15 hingga ke-16. Keberadaan pelabuhan tersebut menunjukkan bahwa sejak dahulu Parepare yang saat itu bernama Bacukiki adalah "kota dunia" dan kota transit tempat bertemu dan berinteraksinya berbagai bangsa. Dengan keberadaan pelabuhan Bacukiki ini, diasumsikan bahwa pada masa itu orang-orang Buddha, baik yang berasal dari China maupun India telah singgah di Parepare, meski jejak-jejak arkeologis dan dokumen historis belum ada catatan pasti. Massifikasi kedatangan penganut Buddha, dalam hal ini yang beretnik Tionghoa di Parepare terjadi ketika masa pemerintahan kolonial Belanda dan menjadikan Parepare sebagai afdeling serta pasca-kemerdekaan RI. Orangorang Tionghoa yang beragama Buddha datang ke Parepaer umumnya untuk berdagang.

\section{Populasi dan Dinamika Internal Umat Buddha di Parepare}

Terdapat perbedaan yang sangat mencolok mengenai data jumlah umat Buddha antara BPS Parepare, BPS Sulsel, dan Kemenag Sulsel maupun Parepare. Dalam buku Parepare dalam angka 2012, tidak terdapat data penduduk berdasarkan agama, namun pada buku Parepare dalam angka 2011, jumlah penganut Buddha sebanyak 1.236 jiwa atau $0,96 \%$ dari penduduk Parepare. Berbeda dengan data tersebut data BPS Sulsel 2012 dan Kanwil Kemenag Sulsel, data penganut Buddha hanya berjumlah 420 jiwa. Sedangkan data dari Kantor Kemenag kota Parepare jumlah penganut Buddha di kota parepare berjumlah 1.826 jiwa. Adapun data dari Pembimas Buddha Kanwil Kemenag Sulsel, jumlah penganut Buddha di kota Parepare adalah 1.398 jiwa.

Perbedaan sangat mencolok dari data populasi umat Buddha antara BPS Sulsel dan data keagamaan yang diterbitkan oleh Kanwil Kemenag Sulsel dengan data umat Buddha di Pembimas Buddha Menurut data BPS atau Kemenag Sulsel, populasi umat Buddha di Sulsel pada tahun 2012 adalah hanya 16.276 jiwa. Sedangkan data populasi umat Buddha di Sulsel menurut data Pembimas adalah 34.849 jiwa.

Setelah peneliti mengkonfirmasi kebeberapa tokoh Buddha di Parepare, tampaknya populasi umat Buddha di Parepare adalah sesuai dengan data Pembimas Buddha Kanwil Sulsel.

Berdasarkan data dari Kemenag kota Parepare, terdapat 1826 orang penganut agama Buddha di Parepare, namun setelah dikonfirmasi dari pihak internal mereka, penganut Buddha di kota Parepare hanya berjumlah 1.398 orang atau hanya sekitar $1 \%$ dari total penduduk kota Parepare. Hampir semua penganut Buddha yang ada di Parepare adalah penduduk keturunan Tionghoa. Dengan demikian, penganut Buddha di Parepare identik dengan etnik Tionghoa, walaupun tidak semua penduduk etnik Tionghoa adalah beragama Buddha dan tidak 
semua penganut agama Buddha adalah berasal dari etnik Tionghoa.

Terdapat empat vihara yang menjadi tempat peribadatan umat Buddha di kota Parepare. Tiga diantaranya berada di kecamatan Soreang dan satu lainnya di kecamatan Ujung. Perbedaan data yang sangat mencolok selain populasi penganut Buddha, data tempat peribadatan (vihara) antara data BPS Sulsel yang bersumber dari data keagamaan Kanwil Kemenag Sulsel dengan data Pembimas Buddha serta kantor Kemenag kota Parepare. Menurut BPS Sulsel dan data keagamaan Kanwil, di Parepare tidak terdapat vihara dan cetya. Sedangkan menurut data Pembimas dan kantor Kemenag kota Parepare dan berdasarkan penelusuran peneliti sendiri, di parepare terdapat empat buah vihara.

Tabel 1. Nama-Nama Vihara di Parepare

\begin{tabular}{llll}
\hline No & Nama Vihara & \multicolumn{1}{c}{ Alamat } & \multicolumn{1}{c}{ Pimpinan } \\
\hline 1 & Kasih Maitreya & $\begin{array}{l}\text { Jl. Pettanarajeng } \\
\text { No 8 }\end{array}$ & Lim Aly Zian \\
2 & $\begin{array}{l}\text { Cakrawala } \\
\text { Dharma }\end{array}$ & Jl. Andi Isa No 11 & $\begin{array}{l}\text { Haryadi } \\
\text { Thamrin }\end{array}$ \\
& Indonesia & & \\
3 & Vimalakirti & $\begin{array}{l}\text { Jl. Lasinrang No } \\
\text { 8-10 }\end{array}$ & $\begin{array}{l}\text { Eka Edy } \\
\text { Antara }\end{array}$ \\
& Buddha Dharma & $\begin{array}{l}\text { Jl. Dg. Parani } \\
\text { No 2 }\end{array}$ & Peter Ho \\
& & \\
\hline
\end{tabular}

Sumber: Pembimas Buddha, 2013.

Vihara-vihara tersebut tidak hanya berfungsi sebagai tempat ibadah, tapi juga berfungsi tempat pembinaan keagamaan umat yang dilakukan oleh masing-masing tokoh vihara, maupun rohaniawan baik Bhikkhu maupun pandita yang datang dari Makassar atau Jakarta. Dua dari empat vihara tersebut yaitu vihara Buddha Dharma dan vihara Kasih Maitreya juga mengelola Sekolah Minggu Buddha (SMB) untuk mengajarkan pelajaran agama Buddha bagi anak-anak umat Buddha yang masih berusia sekolah. Di SMB ini juga para siswa Buddhis mendapatkan mata pelajaran agama Buddha yang tidak didapatkan di sekolah. Keempat vihara tersebut masing-masing dikelola oleh yayasan Buddhis yang berbeda pula, antara pengurus vihara dan yayasan, khususnya posisi ketua biasanya berbeda.

Meski telah lama bermukim di Parepare, geliat umat Buddha di Sulsel dengan memiliki rumah ibadah dan yayasan Buddhis, baru sekitar akhir tahun 1990-an dan tahun 2000-an. Yayasan Buddhis pertama yang berdiri di Parepare adalah Yayasan Kasih Maitreya yang berdiri pada tahun 1998.
Tabel 2. Nama-Nama Yayasan Buddha di Parepare

\begin{tabular}{lllll}
\hline No & \multicolumn{1}{c}{$\begin{array}{c}\text { Nama } \\
\text { Yayasan }\end{array}$} & $\begin{array}{c}\text { Ketua } \\
\text { Yayasan }\end{array}$ & $\begin{array}{c}\text { Tahun } \\
\text { Berdiri }\end{array}$ & \multicolumn{1}{c}{ Alamat } \\
\hline 1 & $\begin{array}{l}\text { Kasih Mai- } \\
\text { treya }\end{array}$ & $\begin{array}{l}\text { Syarif } \\
\text { Wijaya }\end{array}$ & 1998 & Jl. Pettanarajeng \\
2 & $\begin{array}{l}\text { Eka } \\
\text { Dharma } \\
\text { Manggala }\end{array}$ & $\begin{array}{l}\text { Haryadi } \\
\text { Thamrin }\end{array}$ & 2002 & Jl. A. Isa \\
3 & $\begin{array}{l}\text { Buddha } \\
\text { Dharma }\end{array}$ & $\begin{array}{l}\text { Husain } \\
\text { Tan }\end{array}$ & 2003 & Jl. Dg. Parani \\
4 & Vimalakirti & $\begin{array}{l}\text { Eka Edy } \\
\text { Antara Fu }\end{array}$ & 2003 & Jl. Lasinrang \\
\hline
\end{tabular}

Sumber: Data Penyuluh AgamaBuddha Kemenag Kota Parepare, 2013.

Di Parepare terdapat beberapa aliran Buddhis, namun hanya empat aliran yang eksis karena memiliki yayasan dan vihara. Yaitu aliran Theravada (salah satu aliran Buddha arus utama) yang memiliki yayasan dan vihara Buddha Dharma, aliran Maitreya (aliran Buddha yang berasal dari Taiwan) yang memiliki vihara dan Yayasan Kasih Maireya, aliran Nichiren Soshu (aliran Buddha yang berasal dari Jepang) yang memiliki vihara dan Yayasan Vimalakirti, serta aliran I Kuan Tou atau Ikuanisme (aliran Buddha yang berasal dari Taiwan) yang memiliki yayasan dan vihara Cakrawala Dharma Indonesia. Selain keempat aliran tersebut, di Parepare terdapat beberapa umat Buddhis yang menganut aliran Buddha lainnya, seperti Tri Dharma, Buddhayana (MBI), Buddha Mahayana, dan Buddha Vajrayana. Namun, penganut aliranaliran tersebut belum memiliki yayasan dan vihara, dikarenakan jumlah penganutnya yang masih sangat sedikit, bahkan hanya hitungan beberapa orang atau keluarga saja.

\section{Hubungan dan Dinamika Sosial Umat Buddha dan Masyarakat Parepare}

Sepanjang keberadaan penganut Buddha di Parepare tidak pernah ada konflik yang terjadi dengan kelompok agama yang lain, khususnya umat Islam yang merupakan mayoritas di Parepare. Hubungan yang baik antar umat Islam dan penganut agama lain, khususnya penganut Buddha (yang didominasi oleh etnik Tionghoa) telah terbangun sejak dahulu. Mereka tidak membangun "tembok" yang menjadi sekat pemisah antara mereka dengan masyarakat Parepare yang umumnya beragama Islam. Hubungan baik dan harmonis ini tampak, pada penggunaan bahasa Bugis yang cukup fasih diucapkan oleh orang-orang China yang ada di 
Parepare. Hingga saat ini, tidak pernah ada masalah yang timbul akibat disharmoni hubungan antara penganut Buddha sebagai minoritas dan umat Islam sebagai mayoritas di kota Parepare.

Hubungan baik yang dibangun orang-orang Islam dengan kalangan China di Parepare tidak terlepas dari peran tokoh-tokoh agama di kota ini. Dua ulama besar kharismatik yang pernah tinggal di kota ini telah mengajarkan bagaimana hidup berdampingan dan menerima keberadaan orang lain, termasuk orang China. Dua tokoh yang dimaksud adalah AGH. Ambo Dalle dan AGH. Pabbajah. AGH. Ambo Dalle bahkan menjadi tokoh yang dikagumi oleh orang-orang China. Syarif Wijaya atau Sian Wie salah seorang pengusaha China mengungkapkan bahwa AGH Ambo Dalle biasa mengundang mereka ke pesantren jika ada perayaan-perayaan Islam, misalnya Maulid. AGH Ambo Dalle juga kerap mengunjungi tokonya untuk bersilaturrahmi (Syamsurrijal, 2011: 133-134).

Eksistensi umat Buddha sebagai salah satu umat beragama di Parepare diapresiasi dengan mengakomodir dua orang tokoh mereka untuk menjadi anggota FKUB (Forum Kerukunan Umat Beragama) kota Parepare. Kedua orang tersebut adalah Ibu Ngatemi, S.Ag, penyuluh agama Buddha Kemenag kota Parepare dan Bapak Heriyadi Thamrin, ketua yayasan dan vihara Cakrawala Dharma Indonesia.

Hubungan sosial yang baik antara masyarakat Parepare dan penganut Buddha tampak pada kerukunan yang tercipta, masyarakat Parepare tidak pernah menghalang-halangi pembangunan vihara. Berbeda dengan kasus di daerah lainnya, umat Buddha kerap susah membangun vihara.

Contoh kasus di Makassar setidaknya pernah dua kali umat Buddha gagal dalam membangun vihara dikarenakan dihalangi oleh masyarakat sekitar. Kejadian pertama di sekitar tahun 2004 di jalan Sungai Saddang, telah disiapkan tanah untuk pembangunan vihara, namun, tetangga sebelahnya menolak bahkan mengancam jika pembangunan vihara terus dilanjutkan. Kejadian yang sama juga terjadi pada tahun 2011, ketika umat Buddha hendak membangun vihara di sebuah lahan yang telah dibeli di jalan Landak, namun, masyarakat sekitar menghalangi pembangunan vihara tersebut, sehingga pembangunan vihara tidak jadi dilaksanakan dan tanah yang telah disiapkan sebagai lokasi pembangunan vihara kemudian dijual kembali. Kasus yang lebih memprihatinkan lagi terjadi di kecamatan Galesong, kabupaten Takalar.
Sebuah klenteng yang berfungsi sebagai cetya yang telah berusia lebih dari 100 tahun diperintahkan oleh bupati setempat (saat itu dijabat oleh Ibrahim Rewa) untuk ditutup dengan alasan yang tidak masuk akal, yaitu, karena tidak memiliki IMB dan letaknya yang hanya 50 meter dari masjid. Menurut Yonggris Lao, inti alasan sebenarnya adalah, "tidak mau ada yang lain berada di sekitar mereka”.

Agak berbeda dengan masyarakat Parepare cukup terbuka terhadap penganut Buddha dikarenakan antara keduanya telah terjadi interaksi yang terjalin sekian alam tanpa ada tembok eksklusivisme yang menghalangi meski berbeda agama dan etnik. Kegiatan-kegiatan sosial dari vihara dan yayasan Buddhis kerap ditujukan kepada masyarakat umum, khususnya masyarakat yang tinggal di sekitar vihara.

\section{Pelayanan Keagamaan oleh Kementerian Agama Stake Holder dan Bentuk-bentuk Pekayanan}

Untuk lingkungan Kemenag Provinsi Sulawesi Selatan, hanya ada tujuh PNS yang bertugas untuk memberikan pelayanan bagi penganut Buddha di Sulsel. Enam orang adalah tenaga fungsional dan satu orang Pembimas. Praktis dengan sumber daya manusia yang relatif sedikit ini, sangat sulit untuk bekerja maksimal dalam memberikan pelayanan bagi umat. Keenam tenaga fungsional tersebut adalah lima orang guru yang masing-masing, tiga orang di kota Makassar, satu orang di kabupaten Bone, dan satu orang di kota Palopo, dan satu orang lagi adalah penyuluh yang bertugas di kota Parepare. Di Kanwil hanya tersedia seorang Pembimas, yaitu bapak Drs. Ketut Sukanata yang telah bertugas sebagai Pambimas Buddha di Kanwil Sulsel sejak tahun 2003. Beliau bekerja tanpa ketersediaan staf administrasi, sehingga kerja-kerja administrasi dibantu oleh dua tenaga pramubakti yang keduanya adalah muslim.

Di lingkungan Kemenag kota Parepare, untuk pelayanan keagamaan bagi umat Buddha belum disediakan penyelenggara Bimas Buddha. Hanya ada satu orang tenaga PNS dan dua orang tenaga honorer yang disediakan oleh pihak Kemenag kota Parepare dalam pemberian pelayanan keagamaan kepada penganut agama Buddha di kota Parepare. Ketiganya merupakan tenaga teknis penyuluh agama yang disediakan oleh Kemenag Kota Parepare. Satu orang diantaranya berstatus fungsional PNS.

Menurut bapak kepala Kantor Kemenag Kota Parepare, bapak Drs. H. Syafaruddin, M.Ag, 
Kementerian Agama Kota Parepare memberikan pelayanan kepada penganut Buddha di kota Parepare berupa: pelayanan yang bersifat administratif seperti pemberian rekomendasi dalam pendirian rumah ibadah, pemberian rekomendasi guru agama (guru sekolah minggu); pelayanan yang bersifat seremonial dengan menghadiri dan memberikan sambutan dalam acara keagamaan umat Buddha di Parepare; pelayanan dalam peningkatan kualitas kehidupan keagamaan dengan memfasilitasi keberadaan tiga orang penyuluh agama Buddha; serta pelayanan dalam bentuk memfasilitasi pendirian rumah ibadah.

\section{Pelayanan Bidang Penyiaran Agama}

Sebagaimana telah dijelaskan sebelumnya, bahwa pelayanan Kemenag dibidang penyiaran agama untuk penganut agama Buddha di parepare dilayani oleh tiga orang tenaga penyuluh. Satu orang merupakan tenaga penyuluh fungsional PNS bergolongan IIIc, yaitu ibu Ngatemi S.Ag, beliau telah bertugas di Parepare sejak tahun 2004 . Sedangkan dua tenaga penyuluh lainnya adalah penyuluh honorer yang telah di-SK-kan sejak tahun 2011.

Pelayanan penyiaran agama melalui kepenyuluhan agama Buddha dilakukan melalui pembinaan umat baik di Sekolah Minggu Buddhis (SMB), pembinaan wandini (wanita), patria (pemuda), dan pembinaan umum. Untuk ibu Ngatemi selaku penyuluh PNS bertugas melakukan pembinaan di beberapa vihara yang ada di parepare dan menurut beliau sebagai seorang penyuluh tidak membeda-bedakan pelayanan pada tiap vihara maupun aliran yang ada. Sedangkan untuk bapak Tukiman dan ibu Tjia Ai Lan bertugas memberikan pelayanan kepenyuluhan masing-masing di vihara Buddha Dharma dan vihara Kasih Maitreya.

Pelayanan penyiaran agama juga dilakukan dengan mengadakan dan menyemarakkan harihari besar keagamaan Buddha, seperti Waisak maupun hari raya Katina. Dalam peringatan Waisak bersama, pihak Kemenag kota kerap diundang untuk hadir dan kepala kantor Kemenag didaulat untuk memberikan sambutan. Hal ini diakui oleh kepala kantor Kemenag Kota Parepare, bapak Drs.H.Syafaruddin, M.Ag yang menyatakan bahwa beliau kerap hadir dalam acara-acara yang peringatan hari besar keagamaan Buddha dan selalu diminta untuk memberikan sambutan.

\section{Pelayanan Bidang Pendidikan Agama}

Untuk pelayanan di bidang pendidikan agama, pihak Kemenag Kota Parepare belum menyediakan tenaga pendidik atau guru agama Buddha baik PNS maupun honorer, padahal kebutuhan pelayanan pendidikan agama di sekolah sangat dibutuhkan oleh anak-anak umat Buddhis di parepare. Praktis, anak-anak Buddhis yang bersekolah di Parepare tidak mendapatkan pendidikan agama Buddha di sekolah. Mereka hanya mendapatkan pendidikan agama buddha melalui Sekolah Minggu Buddha, dan hanya dua vihara yang saat ini menyelenggarakan SMB, yaitu vihara Kasih Maitreya dan vihara Buddha Dharma, dua vihara lainnya yaitu vihara Vimalakirti dan vihara Cakrawala Dharma belum mengadakan sekolah minggu karena keterbatasan sumber daya pengajar.

Saat ini lebih 100 anak-anak Buddhis di : yang membutuhkan layanan pendidikan agama Buddha di sekolah. Dalam data vihara Buddha Dharma terdapat 46 anak-anak mereka yang usia sekolah dari TK hingga SMA yang membutuhkan layanan pendidikan agama di sekolah. Untuk itu pada bulan Juli tahun 2012, vihara Buddha Dharma Parepare bersurat pada dinas Pendidikan kota Parepare dengan tembusan kepada Kemenag Kota Parepare untuk mengangkat satu guru agama Buddha, dan mereka mengajukan nama calon guru tersebut atas nama Feri Winarsih alumni Dharma Acharya STAB Kartarajasa Malang. Namun, hingga penelitian ini dilakukan, belum ada realisasi dari surat yang diajukan tersebut.

Pelayanan kementerian agama terkait sekolah minggu ini, menurut kepala Kemenag Kota Parepare, Drs. H. Syafaruddin, M. Ag. Pihaknya menerbitkan SK guru sekolah minggu atas permintaan Yayasan Kasih Maitreya untuk SMB Kasih Maitreya, namun, karena belum ada alokasi anggaran honor untuk guru SMB dalam DIPA Kemenag Kota Parepare, sehingga untuk pemberian honor pada guru SMB yang bersangkutan dikembalikan kepada Yayasan Kasih Maitreya. Dengan demikian, pihak Kemenag Kota Parepare belum memberikan bantuan untuk menunjang operasional SMB yang ada di Parepare sebagai bentuk pelayanan keagamaan di bidang pendidikan bagi umat Buddha di Parepare. Bentuk pelayanan yang diberikan baru sebatas pemberian SK yang ditandatangani oleh kepala Kemenag, namun belum mengalokasikan anggaran untuk operasional SMB maupun honor guru SMB.

Jika dari Kemenag Kota Parepaer belum memberikan bantuan terkait operasional SMB 
yang ada di Parepare, bantuan dari Kemenag justru datang dari DIPA Pembimas agama Buddha Kemenag Provinsi Sulsel. Menurut Pembimas Buddha Kemenag Sulsel, bapak Ketut Sukanata, karena alokasi anggaran yang terbatas maka bantuan untuk operasional SMB yang ada di Sulsel digilir setiap tahunnya. Saat ini ada 17 SMB yang ada di Sulsel yang tersebar di empat kota/kabupaten. 12 SMB berada di kota Makassar, dua di kota Parepare, dua SMB di kota Palopo, dan satu SMB di kabupaten Bone. Menurut bapak Ketut Sukanata alokasi anggaran untuk operasional SMB setiap tahunnya hanya Rp. 100 juta, oleh karena itu anggaran tersebut hanya untuk dibagi pada empat SMB. Dan untuk tahun 2013 ini alokasi bantuan operasional untuk SMB dialokasikan untuk dua SMB yang ada di kota Parepare dan dua lagi untuk SMB yang ada di kota Makassar dan di kota Palopo.

\section{Pelayanan Tempat Ibadah}

Sebagaimana telah disebutkan sebelumnya, bahwa di kota Parepare terdapat empat vihara yang dikelola oleh empat yayasan dan masingmasing berafiliasi kepada sekte Buddha yang berbeda. Keempat tempat ibadah tersebut saat ini telah berstatus sebagai vihara yang sebelumnya adalah cetya, dan kini keempatnya telah berstatus bangunan permanen. Cetya Vimalakirti berubah status menjadi vihara pada tahun 2011 dan cetya Dharma Manggala telah berubah status menjadi vihara Cakrawala Dharma Indonesia sejak tahun 2012. Sebelum menjadi vihara dengan bangunan permanen yang berstatus sebagai tempat ibadah, statusnya adalah tempat ibadah sementara yang perizinannya selalu diperbaharui setiap dua tahun sekali.

Sebagaimana dikatakan oleh bapak kepala Kemenag Kota Parepare, pihak Kemenag senantiasa memberi suport bagi pembangunan rumah ibadah bagi umat Buddha di Parepare. Support tersebut dalam bentuk pemberian rekomendasi oleh Kemenag bagi pembangunan vihara. Ketika peresmian vihara, sebagaimana ketika peresmian vihara Cakrawala Dharma pada bulan Juli 2012, pihak Kemenag diundang dan memberikan sambutan dalam acara peresmian vihara tersebut. Dukungan dan suport dari Kemenag ini diakui oleh bapak Heriyadi Thamrin, ketua yayasan dan vihara Cakrawala Dharma Indonesia Parepare. Menurut beliau, pihak Kemenag cukup membantu dalam hal perizinan tempat ibadah mereka mulai dari masih berupa cetya yang izinnya selalu diperbaharui setiap dua tahun, hingga berubah status menajdi vihara secara permanen. Dukungan Kemenag diakui cukup berarti dalam perizinan pembangunan vihara mereka.

Untuk bantuan fisik pembangunan vihara, diakui sendiri oleh kepala Kemenag Kota Parepare, bahwa selama ini pihak Kemenag kota Parepare belum memiliki alokasi anggaran terkait bantuan untuk pembangunan fisik maupun pemeliharaan bangunan vihara dalam DIPA Kemenag Kota Parepare. Hal ini membuat selama ini bentuk bantuan Kemenag Kota Parepare baru sebatas pemberian rekomendasi dan bantuan dalam hal memperoleh izin bagi pembangunan vihara. Sedangkan untuk pemberian bantuan material, pihak Kemenag Kota Parepare, hingga saat ini belum dapat memberikannya.

Sedangkan untuk anggaran bantuan fisik vihara dari DIPA Pembimas Buddha Kanwil Kemenag Sulsel, setiap tahunnya hanya dianggarkan Rp. 20 juta, tentu saja angka yang sangat kecil, apalagi jika mengingat jumlah vihara di seluruh Sulsel semuanya berjumlah 38 vihara yang tersebar di berbagai kota dan kabupaten. Untuk itu, menurut bapak Ketut Sukanata, karena kecilnya anggaran tersebut, setiap tahunnya hanya dialokasikan bantuan untuk dua vihara saja, yang masing-masing vihara menerima bantuan Rp. 10 juta, dan ini hanya untuk bantuan rehabilitasi bangunan vihara, bukan untuk pembangunan vihara. Untuk tahun 2013 ini anggaran tersebut direncanakan untuk membantu dua vihara yang masing-masing berada di kota Makassar dan kota Palopo. Untuk vihara yang ada di kota : , hingga saat ini belum pernah mendapatkan bantuan dana dari Kementerian Agama.

\section{Problem Pelayanan}

Dalam pelaksanaan pelayanan Kemenag terhadap penganut agama Buddha di Parepare, semua informan yang peneliti temui di Parepare menyatakan bahwa dapat dikatakan tidak ada faktor pendukung yang menunjang maksimalisasi dan optimalisasi pelayanan Kementerian Agama yang diberikan kepada penganut agama Buddha. Semua informan menyatakan bahwa, yang ada justru hanya faktor penghambat dalam pelaksanaan pelayanan. Sehingga dapat dikatakan, pelayanan Kementerian Agama terhadap penganut agama Buddha di kota Parepare jauh dari optimal.

Ada beberapa problem dalam pelayanan kepada penganut agama Buddha oleh Kementerian 
Agama di kota Parepare. Beberapa kendala klasik, seperti minimnya SDM, minimnya, alokasi pendanaan, hingga ketiadaan sarana dan prasarana penunjang Pelayanan, serta tidak adanya struktur dalam lingkungan Kementerian Agama Buddha yang difokuskan untuk melayani umat Buddha, dalam hal ini penyelenggara Bimas.

Sebagaimana telah disebutkan sebelumnya bahwa untuk lingkungan Kementerian Agama Buddha hanya menyediakan satu orang tenaga PNS dan dua orang tenaga honorer untuk melayani umat Buddha di Parepare. Tenaga yang disediakan pun hanya tenaga penyuluh agama yang memberikan Pelayanan keagamaan di bidang penyiaran agama. Satu-satunya penyuluh agama Buddha yang berstatus PNS di Kemenag Kota Parepare, yaitu ibu Ngatemi, S. Ag, sehari-harinya juga ditugaskan di bagian umum.

Di bidang pelayanan pendidikan, dalam hal ini ketersediaan tenaga guru agama baik PNS maupun honorer yang menjadi pengajar mata pelajaran agama Buddha di sekolah hingga saat ini tidak ada di kota Parepare. Sehingga anak-anak Buddhis usia sekolah tidak mendapatkan pelajaran agama Buddha di sekolahnya.

Minimnya SDM ini sudah pasti membuat pelayanan jauh dari optimal. Problem SDM ini, tidak hanya terjadi di Parepare, tetapi secara umum merupakan problematika bagi pelayanan kepada penganut agama Buddha di Provinsi Sulsel secara keseluruhan. Secara kuantitas, jumlah SDM yang disediakan jauh dari maksimal. Oleh karena itu, penambahan jumlah SDM sebagai stake holder bagi pelayanan kepada umat Buddha di kota Parepare khususnya menjadi sangat urgen, khususnya ketersediaan SDM di bidang pendidikan, dalam hal ini ketersediaan tenaga guru mata pelajaran agama Buddha di sekolah.

Untuk Kemenag Kota Parepare dapat dikatakan tidak ada alokasi dana untuk operasional pelayanan kepada penganut agama Buddha, kecuali gaji dan insentif tenaga penyuluh. Dana dari DIPA Pembimas sendiri sangatlah minim dan masih jauh dari ideal untuk memberikan pelayanan yang optimal. Ketiadaan dana yang dialokasikan oleh DIPA Kemenag Kota Parepare, tentu saja sangat menghambat optimalisasi pelayanan. Hal ini juga menunjukkan kurangnya perhatian negara, dalam hal ini Kemenag bagi pelayanan terhadap penganut agama minoritas, khususnya penganut agama Buddha di parepare. Dalam melaksanakan pembinaan umat, umat Buddha di Parepare lebih mengandalkan dana swadaya, nyaris tanpa pernah mendapatkan bantuan dari negara, terlebih lagi dari Kemenag kota Parepare.

Ketiadaan sarana dan prasarana penunjang pelayanan, juga membuat pelayanan Kemenag bagi penganut agama Buddha, khsusunya di kota Parepare berjalan jauh dari maksimal. Tidak ada sama sekali bantuan sarana dan prasarana bagi pelayanan kepada penganut Buddha, baik pelayanan di bidang penyiaran agama, pendidikan agama, maupun pembangunan tempat ibadah (vihara dan cetya).

Tidak adanya struktur khusus yang ditugaskan untuk melaksanakan pelayanan bagi penganut agama Buddha di Sulsel, dalam hal ini penyelenggara Bimas untuk tingkat Kemenag kota. Jangankan untuk kota Parepare, di kota Makassar yang populasi umat Buddha mencapai lebih dari 20 ribu jiwa atau sekitar $2 \%$ dari penduduk kota Makassar, di lingkugan Kemenag belum disediakan penyelenggara Bimas Buddha. Ketiadaan struktur penyelenggara Bimas bagi umat Buddha ini tentu saja menjadi kendala bagi maksimalisasi dan optimalisasi terhadap penyelenggaraan pelayanan keagamaan bagi penganut agama Buddha di kota Parepare.

Secara umum dapat dikatakan problem besar terhadap penyelenggaraan Kemenag kepada penganut agama Buddha, khususnya di kota Parepare adalah minimnya perhatian negara, terkhusus Kemenag dalam hal ini. Oleh karenanya, perlu adanya political will yang lebih serius dari penyelenggara negara, khususnya pihak kementerian agama untuk memberikan pelayanan yang adil, proporsional, dan tidak diskriminatif terhadap penganut agama minoritas, khususnya penganut agama Buddha. Sehingga fungsi Kemenag sebagai pelayan bagi semua umat beragama di Indonesia dapat terwujud secara adil.

\section{Tanggapan dan Harapan}

Secara umum, tokoh Buddhis yang peneliti wawancarai terkait tanggapan mereka tentang pelayanan yang telah diberikan oleh pihak Kemenag kepada penganut agama Buddha mengeluhkan bahwa pelayanan yang diberikan masih jauh dari yang diharapkan. Belum optimalnya pelayanan keagamaan yang diberikan kepada penganut agama Buddha tidak hanya terjadi di Parepare, tapi secara umum di Sulawesi Selatan. Menurut 
Yonggris Lao (wakil ketua Walubi Sulsel), Kemenag masih menjadi milik agama tertentu, menurut beliau dapat dikatakan, Kemenag saat ini lebih identik dengan Kemenag Islam. Pihak Kemenag belum menunjukkan political will yang serius untuk melayani semua penganut agama minoritas, termasuk penganut agama Buddha. Oleh karena itu, pelayanan yang diharapkan adalah pelayanan yang benar-benar menerapkan prinsip keadilan dan anti diskriminasi.

Sebagai agama yang diakui dan dilayani, umat Buddha juga berhak mendapatkan pelayanan yang maksimal. Diskriminasi masih sangat kentara dirasakan oleh umat Buddha. Umat Buddha kerap kesulitan dalam memperoleh izin untuk pembangunan rumah ibadah, serta anak-anak Buddhis kesulitan untuk mendapatkan pelajaran agama Buddha di sekolah. Di bidang penyiaran agama, tenaga penyuluh yang hanya satu orang tentu saja sangat mustahil untuk bekerja maksimal dalam memberikan pelayanan penyiaran agama bagi umat Buddha.

Terkait pelayanan keagamaan di Parepare, beberapa tokoh agama yang peneliti temui semua berkomentar, satu orang stake holder yang disediakan oleh Kemenag masih jauh dari cukup. Semua informan menyoroti minimnya SDM Kemenag yang ditugaskan untuk melayani umat Buddha, serta tidak adanya alokasi anggaran yang khusus untuk operasional pelayanan bagi umat Buddha di Parepare. Minimnya berbagai aspek yang terkait penyelenggaraan pelayanan bagi umat Buddha tentu saja sangat memprihatinkan, mengingat umat Buddha juga membutuhkan sentuhan pelayanan dari Kemenag.

Secara spesifik, yang dibutuhkan bagi umat Buddha di Parepare, yang hari ini belum ada, adalah keberadaan tenaga guru agama Buddha di sekolah. Diharapkan pelayanan Kemenag ke depannya adalah mengangkat tenaga guru untuk mata pelajaran agama Buddha di sekolahsekolah di Parepare. Selain itu, untuk Sekolah Minggu Buddha, diharapkan pihak Kemenag kota Parepare memberikan bantuannya sebagai wujud perhatian Kemenag terhadap peningkatan kualitas pemahaman dan penghayatan agama Buddha di kalangan generasi mudanya.

\section{PENUTUP}

Di lingkungan Kemenag kota Parepare, untuk pelayanan keagamaan bagi umat Buddha belum disediakan penyelenggara Bimas Buddha. Hanya satu orang tenaga PNS dan dua orang tenaga honorer yang disediakan oleh pihak Kemenag kota paepare. Ketiganya merupakan tenaga teknis penyuluh agama. Harus diakui pelayanan yang diberikan masih jauh dari maksimal, apalagi berkenaan dengan pelayanan di bidang pendidikan agama dan tempat ibadah. Bentuk-bentuk pelayanan yang diberikan oleh Kemenag kota parepare kepada penganut agama Buddha hingga saat ini masih berupa: 1) pelayanan yang bersifat administratif seperti pemberian rekomendasi dalam pendirian rumah ibadah, pemberian rekomendasi guru agama (guru sekolah minggu). 2) pelayanan yang bersifat seremonial dengan menghadiri dan memberikan sambutan dalam acara keagamaan umat Buddha di parepare, 3) pelayanan dalam bidang penyiaran agama dengan memfasilitasi keberadaan tiga orang penyuluh agama Buddha yang bertugas di lingkungan Kemenag Kota Parepare. 4) pelayanan dalam memfasilitasi perizinan pendirian vihara.

Problem yang dihadapi dalam maksimalisasi penyelenggaraan pelayanan kepada penganut agama Buddha di kota Parepare adalah problem minimnya jumlah SDM selaku stake holder pemberi layanan, tidak adanya alokasi anggaran untuk pelayanan keagamaan kepada penganut agama Buddha oleh Kemenag Kota Parepare, tidak adanya struktur penyelenggara Bimas agama Buddha di lingkungan Kemenag kota Parepare, dan tidak adanya sarana dan prasarana yang menunjang maksimalisasi penyelenggaraan Peayanan yang diberikan kepada penganut agama Buddha.

Secara umum tanggapan tokoh agama dan masyarakat dalam menanggapi pelayanan Kemenag kepada penganut agama Buddha di Parepare menyoroti minimnya pelayanan yang diberikan baik dari segi kuantitas maupun kualitas pelayanan. Masih belum terlihat keseriusan pihak Kemenag dalam memberikan pelayanan yang proporsional sesuai dengan kebutuhan umat Buddha. Oleh karena itu, harapan terhadap pelayanan mestinya harus diberikan secara proporsional dan berbasis kebutuhan umat. Secara spesifik harapan terkait pelayanan kedepannya ditujukan dengan pengangkatan tenaga guru mata pelajaran agama Buddha di sekolah, penambahan jumlah personil penyuluh agama, serta pengalokasian anggaran yang dialokasikan khusus untuk : kepada penganut agama Buddha di kota Parepare. 


\section{UCAPAN TERIMA KASIH}

Peneliti mengucapkan terima kasih kepada Kepala Balai Litbang Agama Makassar, tim redaksi jurnal Al-Qalam, rekan-rekan peneliti, dan seluruh informan atas segala bantuannya dalam memperoleh data, serta kritik dan perbaikan-perbaikan yang disarankan sehingga artikel ini dapat diterbitkan.

\section{DAFTAR PUSTAKA}

Badan Litbang Diklat Kementerian Agama RI. 2010. Rencana Strategis Badan Litbang dan Diklat Kementerian Agama 2010-2014. Jakarta.

Badrun, Pat dkk. 2008.Optimalisasi Pelayanan Keagamaan Departemen Agama. Makassar: Indobis Publishing.

BPS Kota Parepare . Parepare dalam Angka 2011.

Data Keagamaan Kanwil Kementerian Agama Sulsel 2012.

Data Keagamaan Kementerian Agama : 2012.

Data Pembimas Agama Buddha Kanwil Kemenag Sulsel 2011.

Data Penyuluh Agama Buddha Kemenag Kota Parepare 2012.

Endraswara, Suwardi. 2006. Metode, Teori, Teknik Penelitian Kebudayaan: Ideologi, Epistemologi, dan Aplikasi. Yogyakarta: Pustaka Widyatama.

Kawu, Shadiq dan Sabara. 2010. Penyelenggaraan Kepenyuluhan Agama di Parepare. Laporan Penelitian Balai Litbang Agama Makassar.

Kawu, Shadiq dkk. 2011. Spirit Khonghucu: Modal Sosial Merenda Kebangsaan. Jakarta: Orbit.
Kepmenpan No. 63/KEP/M.PAN/7/2003 Tentang : Publik.

Makka, Andi Makmur. 2006. Metode Lebih Indah dari Monte Carlo. Perepare : YPGPU.

Maleong, Lexi J. 2000. Metode Penelitian Kualitatif. Bandung: Rosda Karya.

Mursyid, Ali. 2008. 'pelayanan Keagamaan Bagi Umat Buddha di Palembang. Harmoni 7/1.

Rais, Muhammad. 'Merengkuh Umat Khonghucu di Aras Lokal' dalam Shadiq Kawu Spirit Khonghucu: Modal Sosial Merenda Kebangsaan. Jakarta: Orbit.

Ratminto dan Atik SP. 2007. Manajemen Pelayanan, Pengembangan Model Konseptual, Penerapa. Citizen's Charter dan Standar Pelayanan Mutu. Yogyakarta: Pustaka Pelajar.

Syamsurrijal. 2011. 'Politik Difrensiasi; Mengubah Paradigma Pengakuan Bagi Kaum Minoritas Khonghucu di Indonesia' dalam Shadiq Kawu Spirit Khonghucu: Modal Sosial Merenda Kebangsaan. Jakarta: Orbit.

Sejarah Bimas : dalam www.bimasbuddhakemenag. go.id, diakses 1/5/2013.

Supartini, dkk. 2009. Pola Pembinaan Lembaga Keagamaan Buddha. Jakarta: Dirjen Bimas Buddha. .2007.TeoriOrganisasidanPengorganisasian di Lingkungan Umat Buddha. Jakarta: Yanwreko Wahana Karya.

Sutopo dan Adi Suryanto. 2009. Pelayanan Prima. Jakarta: Lembaga Administrasi NegaraRepublik Indonesia. 